\title{
Structural characterization of the sulfur-capped triangulo cluster, $\mathrm{Cp}_{2} \mathrm{~W}_{2} \mathrm{Fe}(\mathrm{CO})_{7}(\mathrm{~S})$
}

\author{
P. Douglas Williams and M. David Curtis * \\ Department of Chemistry, The University of Michigan, Ann Arbor, Michigan 48109-1055 (U.S.A.) \\ (Received February 29th, 1988)
}

\begin{abstract}
$\mathrm{Cp}_{2} \mathrm{~W}_{2}(\mathrm{CO})_{4}(\mathrm{~W} \equiv \mathrm{W})$ reacts with $\mathrm{Fe}_{2}(\mathrm{CO})_{6}\left(\mu-\mathrm{S}_{2}\right)$ to give $\mathrm{Cp}_{2} \mathrm{~W}_{2} \mathrm{Fe}(\mathrm{CO})_{7}\left(\mu_{3}-\mathrm{S}\right)(1)$ $(10 \%)$ and $\mathrm{Cp}_{2} \mathrm{~W}_{2} \mathrm{Fe}_{2}(\mathrm{CO})_{8}\left(\mu_{3}-\mathrm{S}\right)_{2}(5 \%)$. Spectral properties, cyclic voltammetry, and the structure of 1 are reported. Cluster 1 is a triangulo cluster $\left[\mathrm{CpW}(\mathrm{CO})_{2}\right]_{2}\left(\mathrm{Fe}(\mathrm{CO})_{3}\right)\left(\mu_{3}-\mathrm{S}\right)$, with bond lengths: W-W 3.036(1) $\AA$, W-Fe 2.80(2) (avg.) W-S 2.36(1) $\AA$, and Fe-S 2.204(7) $\AA$. Crystallographic data: $a, b, c$ 16.212(4), 12.657(6), 20.236(8) $\AA ; \beta 113.25(3)^{\circ} ; V$ 3815(2) $\AA^{3} ; Z=8 ; \rho_{\mathrm{c}} 2.72$ $\mathrm{g} / \mathrm{cm}^{3} ; R_{1}=0.070 ; R_{2}=0.10$ on 4060 reflections. A qualitative EHMO scheme is used to rationalize the lack of contraction of the metal-metal bonds which is usually observed when such bonds support bridging sulfide ligands.
\end{abstract}

\section{Introduction}

Sulfided bimetallic clusters which contain a metal from each of the sets $\{\mathrm{Mo}, \mathrm{W}\}$ and $\{\mathrm{Fe}, \mathrm{Co}, \mathrm{Ni}\}$ are of interest in connection to their role as models and precursors for hydrotreating catalysts (HDS, HDN) $[1,2]$ and as sulfur-tolerant CO hydrogenation catalysts [1]. We have reported that $\mathrm{R}_{2} \mathrm{M}_{2}(\mathrm{CO})_{4}(\mathrm{M}=\mathrm{M})(\mathrm{R}=\mathrm{Cp}, \mathrm{Cp}=$ $\left.\mathrm{C}_{5} \mathrm{H}_{4} \mathrm{Me} ; \mathrm{M}=\mathrm{Mo}, \mathrm{W}\right)$ and $[\mathrm{CpMo}(\mu-\mathrm{S})(\mu-\mathrm{SH})]_{2}$ are useful synthons in the rational design of tetranuclear, sulfided bimetallic clusters $[3,4]$. Here we report the synthesis and characterization of a trinuclear cluster, $\mathrm{Cp}_{2} \mathrm{~W}_{2} \mathrm{Fe}(\mathrm{CO})_{7}\left(\mu_{3}-\mathrm{S}\right)(\mathbf{1})$.

\section{Experimental}

All manipulations of reagent solutions were carried out under an atmosphere of prepurified $\mathrm{N}_{2}$. Pure solid products and reagents could be handled for short periods in the open atmosphere. Solvents were carefully dried and degassed prior to use. Elemental analyses were performed by Galbraith Laboratories, Knoxville, TN, or by Spang Microanalytical Laboratory, Eagle Harbor, MI. 
Table 1. Crystallographic statistics

\begin{tabular}{|c|c|}
\hline Color & brick-red \\
\hline $\begin{array}{l}\text { Chem. Formula } \\
\text { Mol. weight }\end{array}$ & $\begin{array}{l}\mathrm{C}_{17} \mathrm{H}_{10} \mathrm{O}_{7} \mathrm{FeSW}_{2} \\
781.87\end{array}$ \\
\hline Space group & $P 2, / a$ \\
\hline$a, b, c,(\AA)$ & $16.212(4), 12.657(6), 20.236(8)$ \\
\hline$\beta(\mathrm{deg})$ & $113.25(3)$ \\
\hline$V\left(\AA^{3}\right)$ & $3815(2)$ \\
\hline$\angle$ & 8 ( 2 independent molecules) \\
\hline$\rho_{\text {calc }}\left(\mathrm{g} / \mathrm{cm}^{3}\right)$ & 2.72 \\
\hline Crystal dimensions (mm) & $0.087 \times 0.124 \times 0.244$ \\
\hline$\mu\left(\mathrm{Mo}-K_{\alpha}, \mathrm{cm}^{-1}\right)$ & 128.46 \\
\hline Scan speed $(\mathrm{deg} / \mathrm{min})$ & $2.5-12$ variable \\
\hline Scan range & $\mathrm{Mo}-K_{\alpha_{1}}-0.8^{\circ}$ to $\mathrm{Mo}-K_{\alpha_{2}}+0.8^{\circ}$ \\
\hline Background/scan time & 0.8 \\
\hline $2 \theta(\mathrm{deg})$ & 45 \\
\hline Reflections measured & $+h+k \pm l$ \\
\hline No. reflections & $5858(4060$ with $I \geq 0.9 \sigma(I))$ \\
\hline$N_{0} / N_{\mathrm{v}}$ & $\mathbf{1 1 . 7}$ for largest block matrix \\
\hline$R_{1}, K_{2}$ & $0.070,0.101$ \\
\hline Residual (e/ $\left.\AA^{3}\right)$ & 2.7 \\
\hline Largest shift/error on final cycle & 1.57 \\
\hline
\end{tabular}

Table 2. Fractional atomic coordinates for $\mathrm{Cp}_{2} \mathrm{~W}_{2} \mathrm{Fe}(\mathrm{CO})_{7} \mathrm{~S}$ (two independent molecules)

\begin{tabular}{|c|c|c|c|c|c|c|c|}
\hline Atom & $x$ & $y$ & $z$ & Atom & $x$ & $y$ & $z$ \\
\hline$W(1 A)$ & $0.0698(01)$ & $0.2038(01)$ & $0.2868(01)$ & $W(2 B)$ & $0.0899(05)$ & $0.3485(05)$ & $-0.2030(02)$ \\
\hline$W(2 A)$ & $0.1204(01)$ & $0.2123(01)$ & $0.4480(01)$ & $W(2 B X)$ & $0.0534(06)$ & $0.3153(06)$ & $-0.2159(03)$ \\
\hline $\mathrm{Fe}(\mathrm{A})$ & $0.2248(02)$ & $0.3062(03)$ & $0.3828(02)$ & $\mathrm{Fe}(\mathrm{B})$ & $-0.0182(05)$ & $0.2447(06)$ & $-0.1446(06)$ \\
\hline $\mathrm{S}(\mathrm{A})$ & $0.0852(04)$ & $0.3502(04)$ & $0.3623(03)$ & $\mathrm{Fe}(\mathrm{BX})$ & $0.0042(08)$ & $0.2529(08)$ & $-0.1030(09)$ \\
\hline$O(1 \mathrm{~A})$ & $0.2655(15)$ & $0.4925(16)$ & $0.3139(11)$ & $S(B)$ & $0.1208(04)$ & $0.1926(04)$ & $-0.1255(03)$ \\
\hline$O(2 A)$ & $0.3405(12)$ & $0.3722(20)$ & $0.5301(11)$ & $\mathrm{O}(1 \mathrm{~B})$ & $-0.1433(15)$ & $0.2265(20)$ & $-0.2884(11)$ \\
\hline$O(3 A)$ & $0.3522(12)$ & $0.1562(16)$ & $0.3652(12)$ & $\mathrm{O}(2 \mathrm{~B})$ & $-0.0669(28)$ & $0.0414(25)$ & $-0.0954(25)$ \\
\hline$O(4 A)$ & $0.1858(14)$ & $0.2823(18)$ & $0.2060(11)$ & $\mathrm{O}(2 \mathrm{BX})$ & $-0.0949(52)$ & $0.0629(57)$ & $-0.1442(36)$ \\
\hline$O(5 A)$ & $0.1889(17)$ & $-0.0010(17)$ & $0.3189(16)$ & $\mathrm{O}(3 \mathrm{~B})$ & $-0.1474(13)$ & $0.3881(18)$ & $-0.1200(13)$ \\
\hline$O(6 A)$ & $0.0038(14)$ & $0.0142(14)$ & $0.3843(10)$ & $\mathrm{O}(4 \mathrm{~B})$ & $0.0317(15)$ & $0.2266(19)$ & $0.0402(11)$ \\
\hline$O(7 A)$ & $0.2945(15)$ & $0.0760(16)$ & $0.4896(12)$ & $\mathrm{O}(5 \mathrm{~B})$ & $0.0387(13)$ & $0.5358(14)$ & $-0.0525(10)$ \\
\hline$C(1 \mathrm{~A})$ & $0.2448(17)$ & $0.4178(17)$ & $0.3396(13)$ & $\mathrm{O}(6 \mathrm{~B})$ & $0.2190(14)$ & $0.5278(19)$ & $-0.1344(14)$ \\
\hline$C(2 A)$ & $0.2951(14)$ & $0.3470(18)$ & $0.4743(14)$ & $O(7 B)$ & $-0.0577(13)$ & $0.5122(16)$ & $-0.2163(10)$ \\
\hline$C(3 A)$ & $0.3033(15)$ & $0.2153(15)$ & $0.3727(13)$ & $C(1 B)$ & $-0.756(37)$ & $0.2395(28)$ & $-0.2403(17)$ \\
\hline$C(4 A)$ & $0.1491(17)$ & $0.2572(24)$ & $0.2392(14)$ & & -0.0 & $0.1249(21)$ & $-0.1152(19)$ \\
\hline$C(5 \mathrm{~A})$ & $0.1476(20)$ & $0.0755(24)$ & $0.3114(14)$ & $C(3 B)$ & $-0.0953(20)$ & $0.3368(23)$ & $-0.1222(15)$ \\
\hline$C(6 \mathrm{~A})$ & $0.0462(20)$ & $0.0911(21)$ & $0.4024(14)$ & $\mathrm{C}(4 \mathrm{~B})$ & $0.0491(29)$ & $0.2454(25)$ & $-0.0034(21)$ \\
\hline$C(7 \mathrm{~A})$ & $0.2287(17)$ & $0.1264(19)$ & $0.4691(14)$ & $C(5 B)$ & $0.0717(15)$ & $0.4614(20)$ & $-0.0510(11)$ \\
\hline$C(8 \mathrm{~A})$ & $-0.0790(18)$ & $0.2659(21)$ & $0.2240(15)$ & $C(6 B)$ & $0.1835(21)$ & $0.4555(25)$ & $0.1345(17)$ \\
\hline$C(9 \mathrm{~A})$ & $-0.0812(18)$ & $0.1634(29)$ & $0.2544(21)$ & $C(7 B)$ & $-0.0084(15)$ & $0.4470(19)$ & $-0.2094(15)$ \\
\hline$C(10 A)$ & $-0.0468(18)$ & $0.0866(26)$ & $0.2238(19)$ & $C(8 B)$ & $0.2326(17)$ & $0.3756(23)$ & $0.0723(15)$ \\
\hline$C(11 A)$ & $-0.0154(18)$ & $0.1361(20)$ & $0.1765(14)$ & $C(9 B)$ & $0.2719(18)$ & $0.4365(25)$ & $0.0361(14)$ \\
\hline$C(12 A)$ & $-0.0363(17)$ & $0.2486(20)$ & $0.1738(12)$ & $C(10 B)$ & $0.3104(19)$ & $0.3568(37)$ & $0.0044(17)$ \\
\hline$C(13 A)$ & $0.1732(22)$ & $0.2248(24)$ & $0.5736(18)$ & $C(11 B)$ & $0.2915(18)$ & $0.2588(23)$ & $0.0163(17)$ \\
\hline$C(14 A)$ & $0.1477(25)$ & $0.3212(27)$ & $0.5496(20)$ & $C(12 B)$ & $0.2488(21)$ & $0.2671(30)$ & $0.0590(18)$ \\
\hline$C(15 A)$ & $0.0539(27)$ & $0.3233(31)$ & $0.5068(21)$ & $C(13 B)$ & $0.0966(22)$ & $0.4091(25)$ & $-0.2993(17)$ \\
\hline$C(16 A)$ & $0.0244(25)$ & $0.2199(35)$ & $0.5064(21)$ & $C(14 B)$ & $0.0250(18)$ & $0.3448(21)$ & $-0.3301(15)$ \\
\hline$C(17 A)$ & $0.1008(24)$ & $0.1552(24)$ & $0.5495(20)$ & $C(15 B)$ & $0.0535(23)$ & $0.2378(26)$ & $-0.3122(18)$ \\
\hline W(1 B) & $0.1437(03)$ & $0.3256(04)$ & $-0.0409(02)$ & $C(16 \mathbf{B})$ & $0.1449(23)$ & $0.2335(28)$ & $-0.2733(16)$ \\
\hline $\mathrm{W}(1 \mathrm{BX})$ & $0.1678(04)$ & $0.3595(06)$ & $-0.0584(03)$ & $C(17 B)$ & $0.1701(20)$ & $0.3474(24)$ & $-0.2702(15)$ \\
\hline
\end{tabular}


Table 3

Selected bond distances $(\AA)$ in $\mathrm{Cp}_{2} \mathrm{~W}_{2} \mathrm{Fe}(\mathrm{CO})_{7} \mathrm{~S}$ (Molecule $\mathrm{A}$ - see text).

\begin{tabular}{|c|c|c|c|}
\hline \multicolumn{4}{|c|}{ Molecule A: Cluster core } \\
\hline$W(1 A)-W(2 A)$ & $3.036(1)$ & $W(1 A)-F e(A)$ & $2.812(3)$ \\
\hline$W(1 A)-S(A)$ & $2.351(6)$ & $W(2 A)-F e(A)$ & $2.788(4)$ \\
\hline$W(2 A)-S(A)$ & $2.366(6)$ & $\mathrm{Fe}(A)-S(A)$ & $2.204(7)$ \\
\hline \multicolumn{4}{|l|}{ Metal-ligand ${ }^{a}$} \\
\hline$W(1 A)-C(4 A)$ & $2.00(3)$ & $W(1 \Lambda)-C(5 \Lambda)$ & $2.00(3)$ \\
\hline $\mathrm{W}(1 \mathrm{~A})-\mathrm{C}(8 \mathrm{~A})$ & $2.37(2)$ & $W(1 A)-C(9 A)$ & $2.33(3)$ \\
\hline$W(1 A)-C(10 A)$ & $2.34(3)$ & $W(1 A)-C(11 A)$ & $2.28(2)$ \\
\hline$W(1 A)-C(12 A)$ & $2.32(2)$ & $W(1 A)-C T(1 A)$ & 1.99() \\
\hline$W(2 A)-C(6 A)$ & $1.94(3)$ & $W(2 A)-C(7 A)$ & $1.96(3)$ \\
\hline$W(2 A)-C(13 A)$ & $2.35(3)$ & $W(2 A)-C(14 A)$ & $2.37(4)$ \\
\hline$W(2 A)-C(15 A)$ & $2.36(5)$ & $W(2 A)-C(16 A)$ & $2.30(5)$ \\
\hline$W(2 A)-C(17 A)$ & $2.31(4)$ & $W(2 A)-C T(2 A)$ & 2.01() \\
\hline $\mathrm{Fe}(\mathrm{A})-\mathrm{C}(1 \mathrm{~A})$ & $1.76(2)$ & $\mathrm{Fe}(\mathrm{A})-\mathrm{C}(2 \mathrm{~A})$ & $1.82(2)$ \\
\hline $\mathrm{Fe}(\mathrm{A})-\mathrm{C}(3 \mathrm{~A})$ & $1.79(2)$ & & \\
\hline \multicolumn{4}{|l|}{ Intraligand } \\
\hline$O(1 A)-C(1 A)$ & $1.19(3)$ & $O(2 A)-C(2 A)$ & $1.12(3)$ \\
\hline$O(3 A)-C(3 A)$ & $1.14(3)$ & $O(4 A)-C(4 A)$ & $1.10(4)$ \\
\hline$O(5 A)-C(5 A)$ & $1.15(4)$ & $O(6 A)-C(6 A)$ & $1.16(3)$ \\
\hline$O(7 \mathbf{A})-C(7 \mathbf{A})$ & $1.17(3)$ & $C(8 A)-C(9 A)$ & $1.44(5)$ \\
\hline$C(8 A)-C(12 A)$ & $1.45(5)$ & $C(9 A)-C(10 A)$ & $1.38(6)$ \\
\hline$C(10 A)-C(11 A)$ & $1.40(5)$ & $C(11 \mathrm{~A})-\mathrm{C}(12 \mathrm{~A})$ & $1.46(4)$ \\
\hline$C(13 A)-C(14 A)$ & $1.32(4)$ & $C(13 A)-C(17 A)$ & $1.39(5)$ \\
\hline$C(14 A)-C(15 A)$ & $1.42(5)$ & $C(15 A)-C(16 A)$ & $1.39(6)$ \\
\hline$C(16 A)-C(17 A)$ & $1.45(5)$ & & \\
\hline
\end{tabular}

${ }^{a} \mathrm{CT}=\mathrm{Cp}$-ring centroid.

Synthesis. A solution of $0.61 \mathrm{~g}(1.0 \mathrm{mmol})$ of $\mathrm{Cp}_{2} \mathrm{~W}_{2}(\mathrm{CO})_{4}$ [5] in $25 \mathrm{ml}$ of toluene was added slowly to a stirred solution of $0.43 \mathrm{~g}(1.0 \mathrm{mmol})$ of $\mathrm{Fe}_{2} \mathrm{~S}_{2}(\mathrm{CO})_{6}$ $[6,7]$ in $15 \mathrm{ml}$ of hexane/toluene $(2 / 1)$. The color darkened to a deep orange, and the mixture was allowed to stir for 30 minutes after addition was complete. The volume of the solution was reduced to ca. $15 \mathrm{ml}$ under vacuum. This concentrated solution was then transferred to a column $(40 \times 3 \mathrm{~cm})$ of alumina, previously dried and degassed under high vacuum for $24 \mathrm{~h}$.

Elution of the column gave the following bands: red $\mathrm{Fe}_{2} \mathrm{~S}_{2}(\mathrm{CO})_{6}$ (hexane eluant), red $\mathrm{Cp}_{2} \mathrm{~W}_{2}(\mathrm{CO})_{6}$ (toluene/hexane 3/1), brown $\mathrm{Cp}_{2} \mathrm{~W}_{2} \mathrm{Fe}_{2}(\mathrm{CO})_{8} \mathrm{~S}_{2}$ (toluene), $\mathrm{Cp}_{2} \mathrm{~W}_{2} \mathrm{Fe}(\mathrm{CO})_{7} \mathrm{~S}$ (1) (toluene), followed by a faint purple-brown fraction $\left(\mathrm{CH}_{2} \mathrm{Cl}_{2}\right)$. A brown, insoluble powder remained at the top of the column. Solvent was removed from each fraction and the resulting solids recrystallized from $\mathrm{CH}_{2} \mathrm{Cl}_{2} /$ hexane. The compound, $\mathrm{Cp}_{2} \mathrm{~W}_{2} \mathrm{Fe}_{2}(\mathrm{CO})_{8} \mathrm{~S}_{2}$, is described elsewhere [3]. The purple-brown fraction gave only a trace of material which was not characterized. Compound 1: $0.08 \mathrm{~g}$ (10\% yield), m.p. $240^{\circ} \mathrm{C}$. Anal.: Found: C, $25.69 ; \mathrm{H}, 1.27 ; \mathrm{S}, 4.28 . \mathrm{C}_{17} \mathrm{H}_{10} \mathrm{FeO}_{7} \mathrm{SW}$ calcd.: C, 26.12; H, 1.29; S, 4.10\%.

Electrochemistry. The cyclic voltammetry of 1 was investigated. The procedure has been described in detail elsewhere [3]. Potentials are vs. an internal ferrocene/ ferricenium couple $\left(E_{\mathrm{p} / 2}+0.07\right.$ vs. $\left.\mathrm{Ag} / \mathrm{AgNO}_{3}\right)(0.01 \mathrm{M}$ in acetonitrile with 0.10 $M \mathrm{Et}_{4} \mathrm{NBF}_{4}$ supporting electrolyte). 
Table 4

Selected bond angles (deg.) for molecule A

\begin{tabular}{|c|c|c|c|}
\hline \multicolumn{4}{|c|}{ Molecule A: Angles about core atoms ${ }^{a}$} \\
\hline $\mathrm{W}(2 \mathrm{~A})-\mathrm{W}(1 \mathrm{~A})-\mathrm{Fe}(\mathrm{A})$ & $56.8(1)$ & $W(2 A)-W(1 A)-S(A)$ & $50.2(1)$ \\
\hline$F e(A)-W(1 A)-S(A)$ & $49.6(2)$ & $W(2 A)-W(1 A)-C(4 A)$ & $123.5(7)$ \\
\hline$F e(A)-W(1 A)-C(4 A)$ & $67.0(7)$ & $S(A)-W(1 A)-C(4 A)$ & $97.1(9)$ \\
\hline$W(2 A)-W(1 A)-C(5 A)$ & $83.4(8)$ & $\mathrm{Fe}(\mathrm{A})-\mathrm{W}(\mathrm{IA})-\mathrm{C}(5 \mathrm{~A})$ & $84.2(8)$ \\
\hline$S(A)-W(1 A)-C(5 A)$ & $125.8(7)$ & $C(4 A)-W(1 A)-C(5 A)$ & $86 .(1)$ \\
\hline$C T(1 A)-W(1 A)-W(2 A)$ & 127.1 & $\mathrm{CT}(1 \mathrm{~A})-\mathrm{W}(1 \mathrm{~A})-\mathrm{Fe}(\mathrm{A})$ & 161.2 \\
\hline$C T(1 A)-W(1 A)-S(A)$ & 116.2 & $C T(1 A)-W(1 A)-C(4 A)$ & 107 \\
\hline $\mathrm{CT}(1 \mathrm{~A})-W(1 \mathrm{~A})-\mathrm{C}(5 \mathrm{~A})$ & 114 & $W(1 A)-W(2 A)-F e(A)$ & $57.6(1)$ \\
\hline$W(1 A)-W(2 A)-S(A)$ & $49.7(1)$ & $\mathrm{Fe}(\mathrm{A})-W(2 \mathrm{~A})-\mathrm{S}(\mathrm{A})$ & $49.8(2)$ \\
\hline$W(1 A)-W(2 A)-C(6 A)$ & $66.9(9)$ & $\mathrm{Fe}(\mathrm{A})-\mathrm{W}(2 \mathrm{~A})-\mathrm{C}(6 \mathrm{~A})$ & $119 .(1)$ \\
\hline$S(A)-W(2 A)-C(6 A)$ & $108.0(8)$ & $W(1 A)-W(2 A)-C(7 A)$ & $93.1(8)$ \\
\hline $\mathrm{Fe}(\mathrm{A})-\mathrm{W}(2 \mathrm{~A})-\mathrm{C}(7 \mathrm{~A})$ & $71.4(9)$ & $S(A)-W(2 A)-C(7 A)$ & $120.3(9)$ \\
\hline$C(6 A)-W(2 A)-C(7 A)$ & $90 .(1)$ & $C T(2 A)-W(2 A)-W(1 A)$ & 154.4 \\
\hline$C T(2 A)-W(2 A)-F e(A)$ & 132.1 & $C T(2 A)-W(2 A)-S(A)$ & 114.2 \\
\hline $\mathrm{CT}(2 \mathrm{~A})-\mathrm{W}(2 \mathrm{~A})-\mathrm{C}(6 \mathrm{~A})$ & 108 & $\mathrm{CT} 2 \mathrm{~A})-\mathrm{W}(2 \mathrm{~A})-\mathrm{C}(7 \mathrm{~A})$ & 112 \\
\hline$W(1 A)-F e(A)-W(2 A)$ & $65.6(1)$ & $W(1 A)-F e(A)-S(A)$ & $54.3(2)$ \\
\hline$W(2 A)-F e(A)-S(A)$ & $55.1(2)$ & $W(1 A)-F e(A)-C(1 A)$ & $108.4(7)$ \\
\hline$W(2 A)-F e(A)-C(1 A)$ & $147.5(9)$ & $S(A)-F e(A)-C(1 A)$ & $94.6(9)$ \\
\hline$W(1 A)-F e(A)-C(2 A)$ & $149.5(9)$ & $W(2 A)-F e(A)-C(2 A)$ & $83.9(9)$ \\
\hline$S(A)-F e(A)-C(2 A)$ & $107.6(9)$ & $C(1 \mathrm{~A})-\mathrm{Fe}(\mathrm{A})-\mathrm{C}(2 \mathrm{~A})$ & $97 .(1)$ \\
\hline$W(1 A)-F e(A)-C(3 A)$ & $96.1(6)$ & $W(2 A)-F e(A)-C(3 A)$ & $111.9(8)$ \\
\hline$S(A)-F e(A)-C(3 A)$ & $150.0(7)$ & $C(1 A)-F e(A)-C(3 A)$ & $100 .(1)$ \\
\hline$C(2 A)-F e(A)-C(3 A)$ & $96 .(1)$ & $W(1 A)-S(A)-W(2 A)$ & $80.1(2)$ \\
\hline$W(1 A)-S(A)-F e(A)$ & $76.2(2)$ & $W(2 A)-S(A)-F e(A)$ & $75.1(2)$ \\
\hline \multicolumn{4}{|l|}{ Angles about ligand atoms } \\
\hline $\mathrm{Fe}(\mathrm{A})-\mathrm{C}(1 \mathrm{~A})-\mathrm{O}(1 \mathrm{~A})$ & $175(2)$ & $\mathrm{Fe}(\mathrm{A})-\mathrm{C}(2 \mathrm{~A})-\mathrm{O}(2 \mathrm{~A})$ & $178(3)$ \\
\hline$F e(A)-C(3 A)-O(3 A)$ & $179(2)$ & $W(1 A)-C(4 A)-O(4 A)$ & $172(2)$ \\
\hline$W(1 A)-C(5 A)-O(5 A)$ & $174(3)$ & $W(2 A)-C(6 A)-O(6 A)$ & $171(3)$ \\
\hline$W(2 A)-C(7 A)-O(7 A)$ & $173(3)$ & $C(9 A)-C(8 A)-C(12)$ & $105(3)$ \\
\hline$C(8 A)-C(9 A)-C(10)$ & $111(4)$ & $C(9 A)-C(10 A)-C(11)$ & $108(3)$ \\
\hline$C(10 A)-C(11 A)-C(12)$ & $109(3)$ & $C(8 A)-C(12 A)-C(11)$ & $107(2)$ \\
\hline$C(14 A)-C(13 A)-C(17)$ & $111(3)$ & $C(13 A)-C(14 A)-C(15)$ & $110(3)$ \\
\hline$C(14 A)-C(15 A)-C(16)$ & $106(3)$ & $C(15 A)-C(16 A)-C(17)$ & $109(3)$ \\
\hline$C(13 A)-C(17 A)-C(16)$ & $105(3)$ & & \\
\hline
\end{tabular}

a $\mathrm{CT}=\mathrm{Cp}$-ring controid.

$X$-ray crystallography. Single crystals of 7 , obtained by slowly cooling a $\mathrm{CH}_{2} \mathrm{Cl}_{2} /$ hexane solution to $-20^{\circ} \mathrm{C}$, were mounted on a Syntex $\mathrm{P} 2{ }_{1}$ diffractometer. The unit cell parameters were determined from 15 centered reflections scattered in reciprocal space. Crystallographic data are collected in Table 1 . The structure was solved and refined with the SHELX76 package of programs [ $\left[{ }^{*}\right]$. The data were corrected for absorption. The unit cell contained 2 independent molecules, one of which (molecule B) was found to be disordered by a rotation of $20-30^{\circ}$ in the $\mathrm{W}_{2} \mathrm{Fe}$ plane. This disorder was modelled by inserting two atom scattering sites for each disordered atom and refining their site occupancies with the constraint that the site occupancy factors sum to 1.0. The final, refined site occupancy factors for

\footnotetext{
* Reference number with asterisk indicates a note in the list of references.
} 
$\{\mathrm{W}(1 \mathrm{~B}), \mathrm{W}(2 \mathrm{~B}), \mathrm{Fe}(\mathrm{B}), \mathrm{O}(2 \mathrm{~B})\}$ and $\{\mathrm{W}(1 \mathrm{BX}), \mathrm{W}(2 \mathrm{BX}), \mathrm{Fe}(\mathrm{BX}), \mathrm{O}(2 \mathrm{BX})\}$ were $0.57(2)$ and $0.43(2)$, respectively.

During several attempts to refine the structure with anisotropic temperature factors, several $\mathrm{Cp}$-carbon atoms became non-positive definite. These atoms $(\mathrm{C}(13 \mathrm{~A})$, $\mathrm{C}(14 \mathrm{~A}), \mathrm{C}(15 \mathrm{~A}), \mathrm{C}(13 \mathrm{~B}), \mathrm{C}(14 \mathrm{~B}), \mathrm{C}(15 \mathrm{~B}))$ were then refined with isotropic temperature factors and all others anisotropic. Blocked full-matrix least squares refinement (up to 350 variables per block) minimized the function $\sum w\left(\left|F_{0}\right|-\left|F_{\mathrm{c}}\right|\right)^{2}$, where the weighting factor, $w=1 /\left(\sigma^{2}\left(F_{0}\right)+0.01 F_{0}^{2}\right)$. All data with $F_{0}>0$ were used in the refinement. Final atomic coordinates are given in Table 2 , and selected bond distances and angles for molecule $A$ are in Tables 3 and 4, respectively. Temperature factors $\left(U_{i j}\right)$ (Table VS) selected bond distances (Table VIS) and bond angles (Table VIIS) for molecules $\mathrm{B}$, and a listing of $F_{0}$ vs. $F_{c}$ (Table VIIIS) are available from the authors (MDC).

\section{Results and discussion}

The reaction of $\mathrm{Fe}_{2} \mathrm{~S}_{2}(\mathrm{CO})_{6}$ with triply bonded complexes, $\mathrm{Cp}_{2} \mathrm{M}_{2}(\mathrm{CO})_{4}(\mathrm{M}=\mathrm{Cr}$, $\mathrm{Mo}, \mathrm{W})$ has been shown to be a useful method of constructing tetranuclear clusters of the type, $\mathrm{M}_{2} \mathrm{M}_{2}^{\prime}\left(\mu_{3}-\mathrm{S}\right)_{2}[3,4,9,10]$. With $\mathrm{Cp}_{2} \mathrm{~W}_{2}(\mathrm{CO})_{4}$, the reaction proceeds to give the isolated products shown in eq. 1.

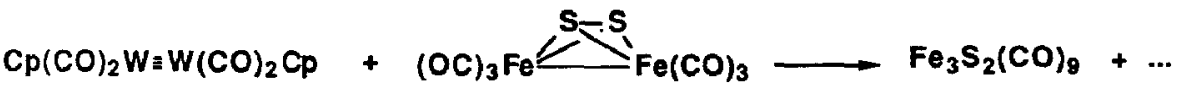

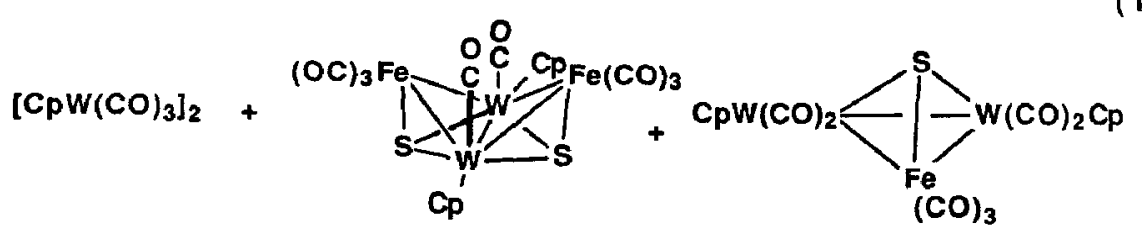

(2) $(5 \%)$

(1) $(10 \%)$

The low yields of the clusters, 1 and 2 , stand in contrast to the analogous reactions of $\mathrm{Fe}_{2} \mathrm{~S}_{2}(\mathrm{CO})_{6}$ with the $\mathrm{Cr}$ and Mo congeners of 3 . The major product of reaction 1 is a brown insoluble solid which was not characterized. The structure of 2 was shown to be isomorphous with its Mo-analog. [3]. A further difference in the reaction of 3 with $\mathrm{Fe}_{2} \mathrm{~S}_{2}(\mathrm{CO})_{6}(4)$ is the formation of the trinuclear cluster, 1 , analogs of which were not observed in the reactions of $\mathrm{Cp}_{2} \mathrm{M}_{2}(\mathrm{CO})_{4}(\mathrm{M}=\mathrm{Cr}, \mathrm{Mo})$ with 4 . The formation of 1 suggests that 4 fragments into " $(\mathrm{CO})_{3} \mathrm{Fe}=\mathrm{S}$ " fragments, isolobal with $R C \equiv C R$, which then add to the $M \equiv M$ triple bond in much the same fashion as observed for acetylenes (cf. eq. 2) [11,12].

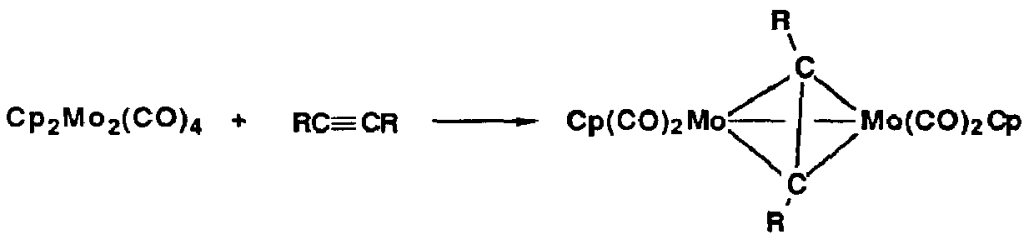

Cluster 1 exhibits CO stretching modes in the IR at 2020s, 1970s, 1940s, 1890w, $1870 \mathrm{~m}$, and $1830 \mathrm{~ms} \mathrm{~cm}^{-1}$. The Cp-protons resonate at $5.37\left(\mathrm{CDCl}_{3}\right.$ solution). A 


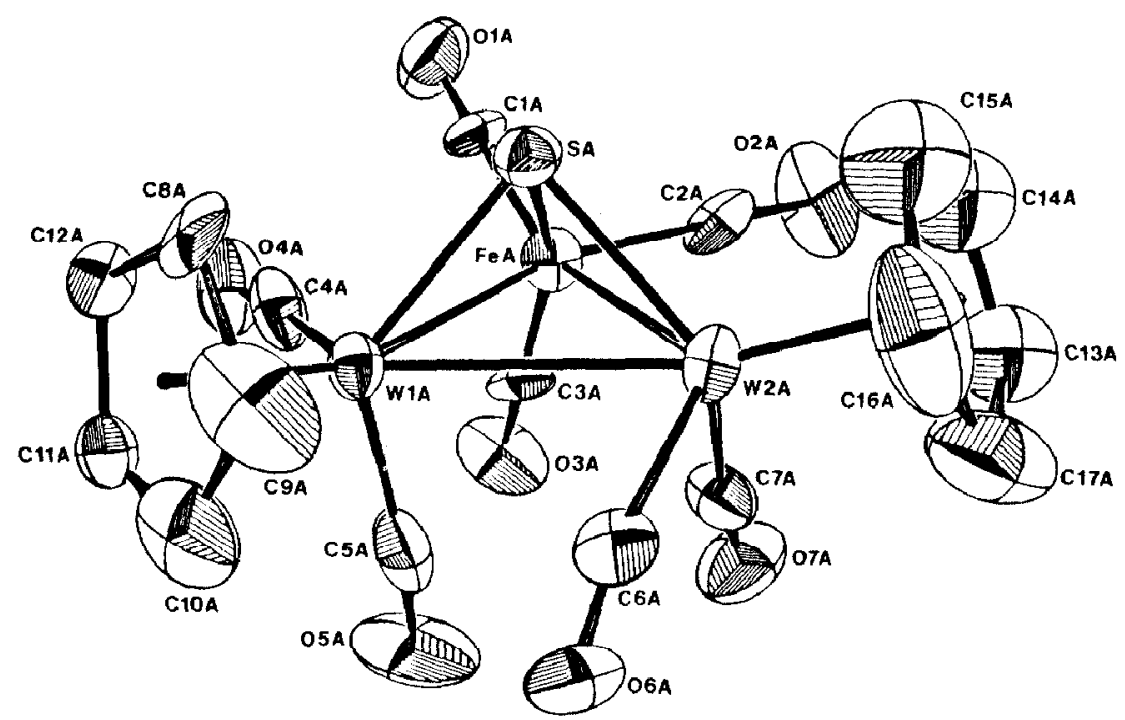

Fig. 1. ORTEP plot of $\mathrm{Cp}_{2} \mathrm{~W}_{2} \mathrm{Fe}(\mathrm{CO})_{7}\left(\mu_{3}-\mathrm{S}\right)(1$, molecule $\mathrm{A})$. Thermal ellipsoids are drawn at the $50 \%$ probability level.

shoulder at $445 \mathrm{~nm}$ is observed in the UV absorption spectrum. Cluster 1 has also been synthesized by Vahrenkamp et al. by the transmetallation reaction of $\mathrm{CpWCoFe}(\mathrm{CO})_{8}\left(\mu_{3}-\mathrm{S}\right)$ with $\mathrm{Cp}(\mathrm{CO})_{3} \mathrm{WAsMe}_{2}$ [13]. The spectral properties reported here are in good agreement with those reported previously.

Electrochemistry. Reduction of the $\mathrm{W}_{2} \mathrm{Fe}\left(\mu_{3}-\mathrm{S}\right)$ cluster gave one broad cathodic wave with a peak potential $E_{\mathrm{p}}=-1.68 \mathrm{~V}$ (peak A) vs. the $\mathrm{Fc} / \mathrm{Fc}^{+}$couple. The peak height seemed to be characteristic of a le-reduction. On the return sweep, two

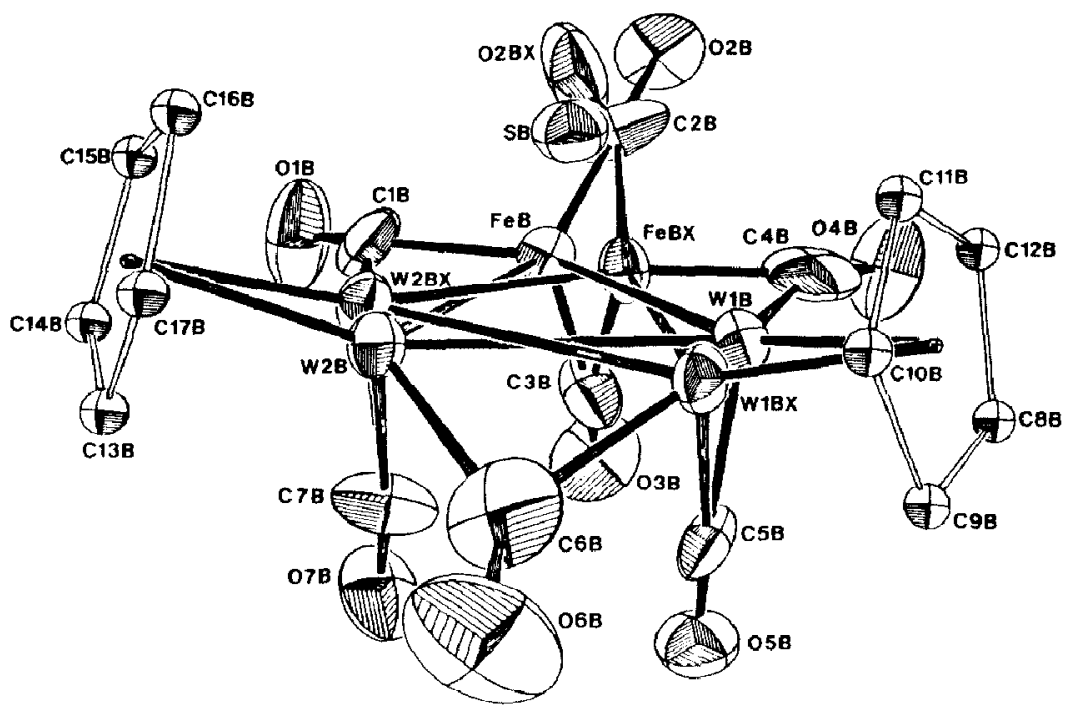

Fig. 2. ORTEP plot of 1 (molecule B) which illustrates the disorder model. Bands to the capping S-atom are omitted and the thermal ellipsoids for the $\mathrm{Cp}$-carbons are set artificially low for clarity. The remaining thermal ellipsoids are drawn at the $50 \%$ probability level. 


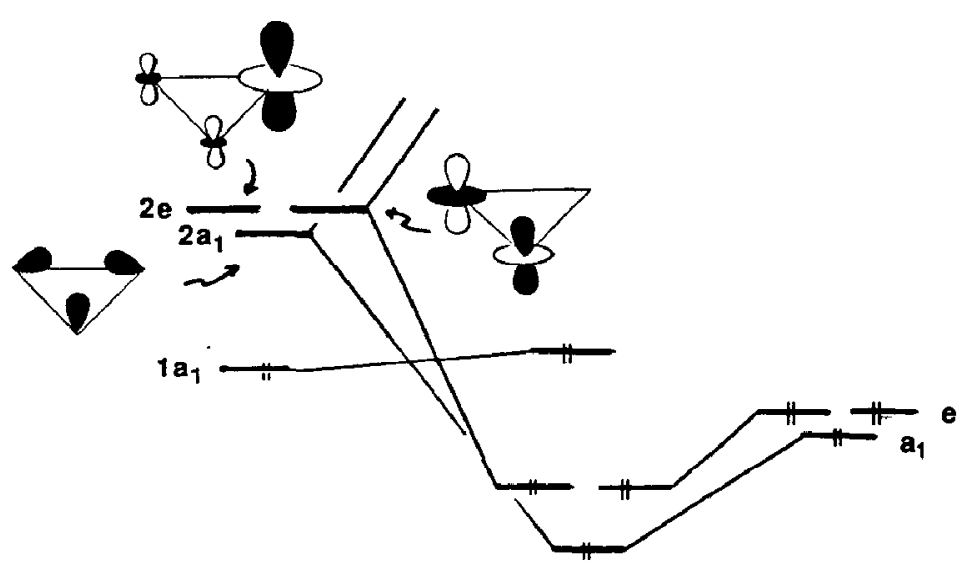

Scheme 1.

anodic peaks were observed $E_{\mathrm{p}}=-1.46 \mathrm{~V}$ (peak B) and $E_{\mathrm{p}}=-1.20 \mathrm{~V}$ (peak C). The current ratio of peak $B$ to peak $A$ was 0.40 and was independent of the sweep rate. The currents of peaks $B$ and $C$ were about equal for all sweeps rates (25-200 $\mathrm{mV} / \mathrm{s}$ ) examined. Thus, it appears that upon initial reduction, the cluster structure reorganizes by two, parallel, fast chemical steps to produce species $\mathrm{X}^{-}$and $\mathrm{Y}^{-}$in approximately equal amounts. Similar behavior has been observed for the tetranuclear clusters, $\mathbf{M}_{2} \mathbf{M}_{2}^{\prime} \mathbf{S}_{2-4}$ [3]. A single, irreversible anodic wave was observed at $+0.48 \mathrm{~V}$.

Structure of 1 . The unit cell of 1 contains two independent molecules, A and B. Molecule A was ordered (Fig. 1) while molecule B was disordered. Figure 2 is an ORTEP drawing which shows the nature of the disorder. Within the ligand cage, one $\mathrm{W}_{2} \mathrm{Fe}$ triangle is rotated with respect to another by $20-30^{\circ}$. Subsequent discussion will focus on the metrical parameters derived from the ordered molecule, A.

The cluster core consists of a S-capped $\mathrm{W}_{2} \mathrm{Fe}$ triangle. The $\mathrm{W}-\mathrm{W}$ distance, 3.036(1) $\AA$, is indicative of a normal W-W single bond as found in many $\mathrm{Cp}(\mathrm{CO})_{n} \mathrm{~W}$ complexes. The $\mathrm{W}-\mathrm{Fe}$ distances (avg. $2.80(2) \AA$ ) reflects the expected difference in the covalent radii of $\mathrm{W}$ and $\mathrm{Fe}$. The $\mathrm{W}-\mathrm{S}$ distances (avg. 2.36(1) $\AA$ ) and the $\mathrm{Fe}-\mathrm{S}$ distance $(2.204(7) \AA)$ are also normal *.

It is interesting to note that the metal-metal distances in $\mu_{3}-\mathrm{S}$ capped, triangulo clusters do not show the marked $\mathbf{M}-\mathbf{M}$ bond contractions observed when the $\mathbf{M}-\mathbf{M}$ bond is bridged by 2 or more sulfide ligands [3]. This observed contraction (up to ca. $0.4 \AA$ for 4 bridging sulfides) has been rationalized by noting that $M-S-M$ bonding orbitals have $\mathbf{M}-\mathbf{M} \pi$-bonding character. The lack of contraction in the $\mathbf{M}_{3}\left(\mu_{3}-\mathrm{S}\right)$ clusters may be rationalized by a parallel argument.

According to the EHMO analysis by Schilling and Hoffman [14], the LUMO (acceptor orbitals) of a $M_{3} L_{9}$ fragment have symmetry $a_{1}+e$. These orbitals are diagrammed in Scheme 1. Because of their excellent overlap with the sulfur

\footnotetext{
* Standard deviations of individual values, derived from the variance-covariance matrix, are enclosed in parentheses. Standard deviations of average values, calculated by the $N-1$ formula, are enclosed in square brackets.
} 
$3 p$-orbitals (which also transform as $a_{1}+c$ ) of the $\mu_{3}-S$ ligand, the primary bonding between the $\mu_{3}$-S and the $\mathrm{M}_{3}$-triangle involves the interaction of the $\mathrm{S}\left(a_{1}+e\right)$ $3 p$-orbitals and the $2 a_{1}+2 e$ orbitals of the $\mathrm{M}_{3} \mathrm{~L}_{9}$ fragment (see Fig. 3 of ref. 14). This interaction is diagrammed in Scheme 1.

As a result of the M-S bond formation, the metal-metal $2 a_{1}+2 e$ fragment orbitals become occupied. The $2 a_{1}$ orbital is weakly $\mathbf{M}-\mathbf{M}$ bonding, but the $2 e$ orbital is $\mathrm{M}-\mathrm{M}$ antibonding. Consequently, population of the $2 a_{1}+2 e$ orbitals does not lead to additional strengthening of the $\mathbf{M}-\mathbf{M}$ bonds. In contrast, $\mathbf{M}-\mathbf{M}$ $\pi$-orbitals are populated when the $\mathrm{M}-\mathrm{M}$ bond is flanked by 2 or more bridging sulfides, and a significant $\mathrm{M}-\mathrm{M}$ bond contraction results.

\section{Acknowledgements}

Support from the National Science Foundation (CHE-8305235) is gratefully acknowledged. P.D. Williams also thanks the donors for Samuel H. Baer and Rackham Predoctoral Fellowships. Assistance with X-ray data collection and structure solution was provided by Dr. W.M. Butler.

\section{References}

1 (a) M.D. Curtis, J. Schwank, L. Thompson, P.D. Williams, and O. Baralt, Prepr. Pap. -Am. Chem. Soc. Div. Fuel Chem., 31 (1986) 44; (b) M.D. Curtis, J.W. Schwank, L.T. Thompson, and P.D. Williams, U.S. Pat. 4,605,751, Aug. 12, 1986. (c) M.D. Curtis, J.E. Penner-Hahn, J. Schwank, O. Baralt, D.J. McCabe, L. Thompson, and G. Waldo, Polyhedron, in press.

2 (a) P. Ratnasamy and S. Sivasankcr, Catal. Rev.-Sci. Eng., 22 (1980) 401; (b) N.Y. Topsoe and H. Topsoe, J. Catal., 84 (1983) 386; (c) B. Clausen, H. Topsoe, R. Candia, and B. Langeler, Springer Proc. Phys., 2 (1984) 181.

3 M.D. Curtis, P.D. Williams, and W.M. Butler, Inorg. Chem, in press.

4 (a) P.D. Williams, M.D. Curtis, D.N. Duffy, and W.M. Butler, Organometallics, 2 (1983) 165; (b) M.D. Curtis and P.D. Williams, Inorg. Chem., 22 (1983) 2661.

5 M.D. Curtis, N.A. Fotinos, L. Messerle, and A.P. Sattelberger, Inorg. Chem., 22 (1983) 1559.

6 D. Seyferth, R.C. Henderson, and L.-C. Song, Organometallies, 1 (1982) 125.

7 L.E. Bogan, D.A. Lesch, and T.B. Rauchfuss, J. Organomet. Chem., 250 (1983) 429.

8 Computations were performed on an Amdahl 470/V7 computer at the University of Michigan Computing Center. The program SHELXSYNOBJ (W.M. Butler, University of Michigan) was used to apply Lorentz and polarization corrections and to format the data. Programs used in the structure determination and refinement were contained in the program package SHELX76 (G. Sheldrick, Institut für Anorganische Chemie der Universität Göttingen). ORTEP (C.K. Johnson) was used to generate thermal ellipsoid plots.

9 P. Braunstein, A. Tiripicchio, M.T. Camellini, and E. Sappa, Inorg. Chem., 20 (1981) 3586.

10 P. Braunstein, J.M. Jud, A. Tiripicchio, M.T. Camellini, and E. Sappa, Angew. Chem. Int. Ed. Engl., 21 (1982) 307.

11 M.D. Curtis and R.J. Klingler, J. Organomet. Chem., 161 (1978) 23.

12 W.I. Bailey, Jr., M.H. Chisholm, F.A. Cotton, and L.A. Rankel, J. Am. Chem. Soc., 100 (1978) 5764.

13 F. Richter, E. Roland, and H. Vahrenkamp, Chem. Ber., 117 (1984) 2429.

14 B.E.R. Schilling and R. Hoffmann, J. Am. Chem. Soc., 103 (1979) 3456. 